\title{
Meiofaunal communities in a tropical seagrass bed and adjacent unvegetated sediments with note on sufficient sample size for determining local diversity indices
}

\author{
Jian-Xiang Liao ${ }^{1 *}$, Hsin-Ming Yeh² and Hin-Kiu Mok ${ }^{1}$
}

\begin{abstract}
Background: Seagrass beds are highly diverse and productive marine habitats for many associated organisms in nearshore coastal waters. The differences in abundance, diversity, and community structure of benthic invertebrates between seagrass beds and adjacent unvegetated sediments have been stated, whereas most studies are primarily focused on macrofauna or based on a comparatively long distance, i.e., more than $10 \mathrm{~m}$. The present study is designed to test if the community structures of meiofauna, especially the free-living nematodes, differ between seagrass beds and adjacent unvegetated sediments on a meter scale.

Results: There are 21 meiofaunal taxa and 63 nematode genera that have been identified from a tropical seagrass bed of Thalassia hemprichii in Ludao, Taiwan. Although the compositions of higher meiofaunal taxa are undistinguished, according to correspondence analysis, the assemblages of nematode genera differ substantially between the seagrass bed and unvegetated sediments. Regarding the nematodes, approximately $50 \%$ of genera are restricted to the seagrass bed whereas $6 \%$ are restricted to unvegetated sediments, which indicate both habitats possessing distinct infaunas. The number of replicates for reasonable estimation of the local diversity index is calculated by the randomization technique. For local seagrass beds, only a single core is sufficient for reliably estimating meiofaunal diversity, but at least three cores or a sample size of 300 individuals is needed for the nematode community.
\end{abstract}

Conclusions: Nematode assemblages provide more particular differences between seagrass and unvegetated habitats than meiofaunal communities on small spatial scales. Both seagrass beds and adjacent unvegetated sediments harbor specific meiofaunal communities, and hence, the conservation strategy for seagrass should also consider the peripheral bare area of seagrass beds.

Keywords: Meiobenthos; Thalassia hemprichii; Community composition; Marine nematode; Randomization; Diversity index

\section{Background}

Seagrass beds, which distribute widely in tropical and temperate coastal regions, are one of the most productive marine ecosystems (Duarte and Chiscano 1999). Thalli, roots, and rhizomes of seagrasses offer associated animals microhabitats and shelters (Osenga and Coull 1983; Orth et al. 1984; Castel et al. 1989; Atilla et al. 2005). In

\footnotetext{
* Correspondence: jianxiangliao@gmail.com

'Department of Oceanography, National Sun Yat-sen University, Lienhai Road 70, Kaohsiung 80424, Taiwan

Full list of author information is available at the end of the article
}

addition, various detritus and organic particles in seagrass beds enhance the density and heterogeneity of infauna (Hall and Bell 1993; Danovaro et al. 2002). Meiofauna, benthic organisms between $1 \mathrm{~mm}$ and $42 \mu \mathrm{m}$, is considered a trophic level between microfauna and macrofauna (animals larger than $1 \mathrm{~mm}$ ). However, most studies dealing with seagrass beds merely focus on macrofauna, even though meiofauna can consume from $10 \%$ to more than $50 \%$ of the total primary production in a seagrass system (Danovaro et al. 2002). Moreover, most members of meiofauna are less influenced by hypoxia and predation than 
those of macrofauna and have distinct responses to environmental changes (Josefson and Widbom 1988; Castel et al. 1989; Giere 2009). Among meiofaunal communities, free-living nematodes usually constitute the most abundant taxa, albeit seagrass studies of meiofauna have primarily focused on epifauna, i.e., harpacticoid copepods. Nematode assemblages shift consistently with ambient sediments, and they are considered an ecological indicator (Bongers and Ferris 1999).

The unvegetated area around seagrass patches facilitates infauna dispersal and can be a matrix habitat, but few seagrass studies have looked into this bare region (Boström et al. 2006). The abundance and community structure of nematodes show substantial differences between vegetated and peripheral unvegetated sites (Fisher and Sheaves 2003; Hourston et al. 2005; Monthum and Aryuthaka 2006; Fonseca et al. 2011; Leduc and Probert 2011), although no difference between both habitats has also been reported (Ndaro and Ólafsson 1999). The variability in nematode populations on a small spatial scale (centimeter scale) accounts for $30 \%$ and $43 \%$ in intertidal and shallow subtidal sediments, respectively (Hodda 1990; Li et al. 1997). However, the distances between samples or quadrats in most seagrass studies are separated by more than $10 \mathrm{~m}$ or unmentioned (except Hourston et al. 2005; $2 \mathrm{~m}$ ), whereas the other unanticipated local environmental factors (e.g., water depth) exceed the effect of seagrass (Mills and Berkenbusch 2009). Comparisons between seagrass beds and peripheral unvegetated sediments at small-scale distances elucidate the seagrass effect on meiofaunal communities.

Diversity indices are widely used in ecological research, especially for comparative purposes. The Shannon-Wiener index $\left(H^{\prime}\right)$ is the most popular one for measuring diversity in a community. Because of the sample size dependence, a pertinent sampling effort is required for comparison between various communities. The randomization technique has been used to estimate the sufficient sample size for obtaining an approximate value of the diversity index (Soetaert and Heip 1990). However, Hurlbert's modified rarefaction curve (Hurlbert 1971) or the expected species richness, $\mathrm{ES}(n)$, a sample size-independent index of species richness (Sanders 1968), is much more often used to estimate the diversity of meiofauna (e.g., Shimanaga et al. 2004; Leduc et al. 2010). In addition, most relevant investigations are performed in temperate regions or the deep sea, but the same procedure may not be appropriate for tropical habitats. To our knowledge, there is an absent or scarce report on the marine meiofaunal communities in Taiwan, and a relevant method for determining local diversity indices might improve the future comparison with the other regions.

The present study aims to inspect the community structure of meiofauna, particularly nematodes, which are used to examine the difference between seagrass beds and adjacent unvegetated sediments on a meter scale. Meiofaunal samples were collected quantitatively from sediments below the sickle seagrass Thalassia hemprichii and peripheral unvegetated substrates in Ludao, Taiwan. The sampling effort (i.e., the number of replicates) required for estimating the local diversity index in a seagrass habitat is determined using a randomization test to provide a basis for future experimental design of comparative researches.

\section{Methods}

\section{Study site and sampling methods}

Shihlang is a recreational diving site in Ludao, also known as Green Island, situated off the southeastern coast of Taiwan (Figure 1). The shore is composed of a sandy platform extending $50 \mathrm{~m}$ seaward and a $T$. hemprichii meadow $\left(22^{\circ} 39^{\prime} 08^{\prime \prime} \mathrm{N}, 121^{\circ} 28^{\prime} 25^{\prime \prime} \mathrm{E}\right)$ in the littoral zone. Patches of seagrass distribute at a region $150 \mathrm{~m}$ in length and $12 \mathrm{~m}$ in width along the coast. The distance between the fringes of seagrass beds to the mean high water line is about $18 \mathrm{~m}$. Because of the freshwater input, the salinity reaches approximately 20 to 25 practical salinity units (PSU) during low tide. Megafaunal bioturbators are frequently present, mainly composed of crustaceans and echinoderms.

Regarding the narrow distribution of the seagrass patches and avoiding intense environmental changes, four $5 \times 5 \mathrm{~m}$ side-by-side sampling quadrats were selected: three seagrass patches and an adjacent unvegetated control quadrat. The vegetated quadrats densely grew $T$. hemprichii and patches with sparse region, where taking cores was avoided. Within each quadrat, five replicate cores for meiofauna were sampled by a lower end cutoff syringe (diameter $=2 \mathrm{~cm}$ ), which was pushed into the sediment to a depth of $5 \mathrm{~cm}$. On each sampling occasion, the replicates were at least $1 \mathrm{~m}$ apart from each other. All samples collected from the area were $20 \mathrm{~m}$ long and $5 \mathrm{~m}$ wide at approximately 30-cm water depth during low tide on 17 March 2012. Samples of meiofauna were anesthetized using $7 \% \mathrm{MgCl}_{2}$ solution to promote tissue relaxation and then preserved with formaldehyde to a final concentration of $4 \%$. The sediment grain size profile was very similar to the sandy platform, and five additional replicate cores were taken for sediment granulometry as a reference.

\section{Laboratory procedures}

Meiofaunal samples were stained with $0.5 \mathrm{~g} / \mathrm{L}$ Rose Bengal for $1 \mathrm{~h}$ and washed through sieves of 1,000- and $42-\mu \mathrm{m}$ mesh size. All the meiofauna retained on the 42- $\mu \mathrm{m}$ sieve were extracted, counted, and identified to the major taxon level under a stereomicroscope. From each replicate, 100 nematodes (or all individuals if fewer) were picked out, transferred to pure glycerol, mounted onto permanent slides, and identified to the genus level 


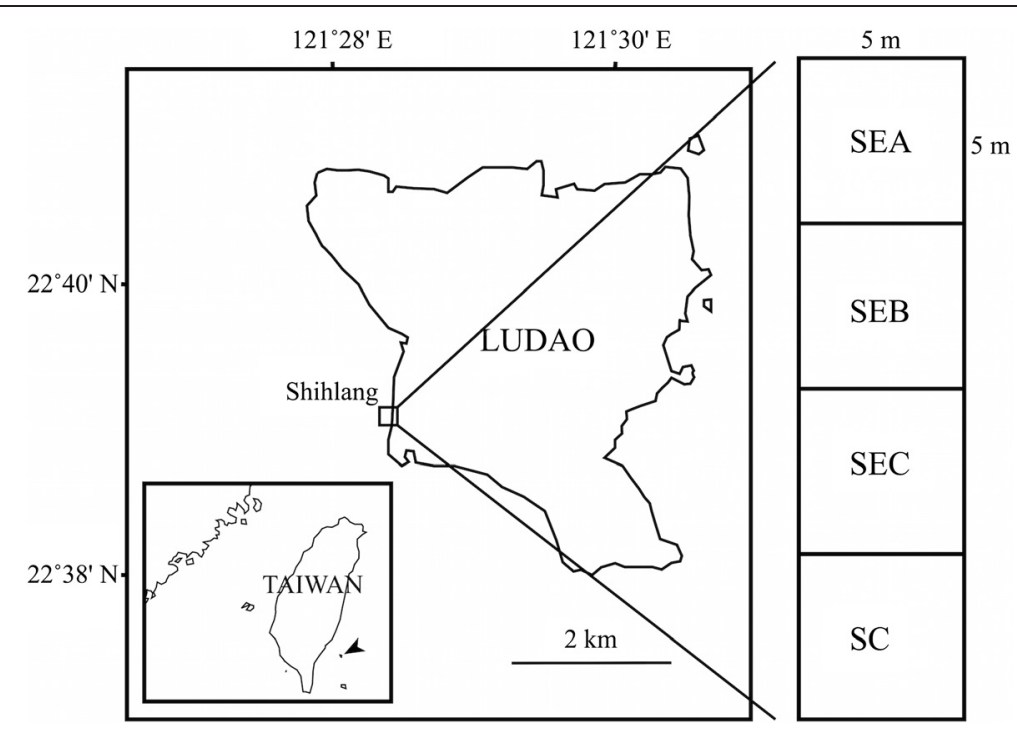

Figure 1 Map of the sampling site in Shihlang (Ludao) with indication of the quadrats. SC, unvegetated quadrat; SEA, SEB, and SEC, seagrass quadrats.

using the pictorial keys (Platt and Warwick 1988; Warwick et al. 1998). The trophic types of nematodes were classified by the morphology of buccal cavities (Wieser 1953). For granulometric analysis, sediment samples were first washed with freshwater to remove salt, dried at $60^{\circ} \mathrm{C}$ for $48 \mathrm{~h}$, and then separated out on mesh sizes of 1,000, 500, 250, 125, and $62 \mu \mathrm{m}$.

\section{Statistical analyses}

Multivariate and univariate statistical methods were used to discriminate meiofaunal communities and nematode assemblages between seagrass beds and unvegetated sediments. Community structures were examined using classification and ordination methods to test the consistency of the core replicates. Cluster analysis based on the similarity of the Morisita-Horn index (Horn 1966), which was independent of sample size and diversity, was conducted to group the subsamples. The unweighted pair group method with arithmetic mean (UPGMA) was used to construct the dendrograms. Correspondence analysis (CA) was selected as the ordination method for appropriating to species abundance data. Scaling type 1 (Legendre and Legendre 1998) was chosen for preserving the chi-square distances between sites. For meiofauna and nematode assemblages, the abundance data were square root transformed to reduce the skewness before the multivariate analysis. The square root transformation was used to balance between retaining quantitative information and downweighting the dominant taxa.

The randomization technique was used to calculate a sufficient number of replicates for achieving a reasonable estimate of the diversity index in the sampling site (Soetaert and Heip 1990). According to the results of cluster analysis and CA, if the replicates from identical quadrats were not clustered an obvious group, the abundance data of these replicates were pooled. The numbers of individuals among the core replicates were highly variable, so the mean abundance of meiofauna was chosen as a representative sample size for calculating efficiency. Regarding nematodes, 100 individuals, the most commonly selected number for taxonomic identification, were used to simulate a given sample. All abundance data of seagrass beds were pooled for the randomization simulation by Yeh's computer program (Yeh and Ohta 2002). Pooled data were randomly selected to achieve the predetermined number of sample sizes. The significant differences of ten replicates of the Shannon-Wiener index $\left(H^{\prime}\right)$ among every dissimilar sample sizes were examined using the Kruskal-Wallis test. Dunn's test for multiple comparisons was used to determine which values differed significantly if the Kruskal-Wallis test revealed a significant difference.

\section{Results}

\section{Environmental and biological variables}

The quadrats covered an area $20 \mathrm{~m}$ long and $5 \mathrm{~m}$ wide, where salinity was approximately 20 PSU during the sampling occurrence at low tide. Sediment grain sizes $(n=5)$ showed peaks around coarse $(500$ to $1,000 \mu \mathrm{m})$ or very coarse $(1,000$ to $2,000 \mu \mathrm{m})$ sand, with the average median grain size $537 \pm 51 \mu \mathrm{m}$ and very few silt $(<62 \mu \mathrm{m})$ contents $(<1 \%)$.

A total of 21 meiofaunal taxa were identified in the present study (Table 1). Meiofaunal density in the top $5 \mathrm{~cm}$ of sediments varied between 188 and 2,978 individuals $10 \mathrm{~cm}^{-2}$, whereas mean densities showed 1,172 and 1,345 individuals $10 \mathrm{~cm}^{-2}$ for vegetated and unvegetated 


\begin{tabular}{|c|c|c|c|c|}
\hline \multirow{2}{*}{$\begin{array}{l}\text { Higher } \\
\text { meiofaunal taxa }\end{array}$} & \multicolumn{2}{|c|}{ Seagrass $(n=15)$} & \multicolumn{2}{|c|}{ Unvegetated $(n=5)$} \\
\hline & Mean & SD & Mean & SD \\
\hline Acari & 1.5 & 2.0 & 1.3 & 0.6 \\
\hline Amphipoda & 3.2 & 4.8 & 0.6 & 0.3 \\
\hline Bivalvia & 0.2 & 0.8 & 0.6 & 0.3 \\
\hline Ciliophora & 11.0 & 11.2 & 3.8 & 1.0 \\
\hline Copepoda & 160.7 & 201.6 & 607.6 & 82.3 \\
\hline Cnidaria & 0.8 & 1.9 & 1.3 & 0.6 \\
\hline Foraminifera & & & 0.6 & 0.3 \\
\hline Gastropoda & & & 1.3 & 0.3 \\
\hline Gastrotricha & 3.6 & 4.0 & 0.6 & 0.3 \\
\hline Hirudinea & 0.2 & 0.8 & & \\
\hline Isopoda & 7.4 & 15.8 & & \\
\hline Nauplius & 16.6 & 45.1 & 138.9 & 30.6 \\
\hline Nematoda & 853.3 & 731.1 & 475.8 & 126.0 \\
\hline Nemertea & 1.1 & 2.0 & & \\
\hline Oligochaeta & 5.9 & 8.2 & & \\
\hline Ostracoda & 5.7 & 7.1 & 22.3 & 4.7 \\
\hline Polychaeta & 71.5 & 97.6 & 69.4 & 12.6 \\
\hline Rotifera & 0.2 & 0.8 & & \\
\hline Sipuncula & 0.4 & 1.1 & 0.6 & 0.3 \\
\hline Turbellaria & 28.7 & 20.5 & 15.3 & 4.3 \\
\hline Undetermined egg & & & 4.5 & 1.0 \\
\hline
\end{tabular}

The mean and standard deviation (SD) of each meiofaunal taxon are shown in individuals per $10 \mathrm{~cm}^{2}$

sites, respectively. Nematoda was the most abundant taxon $(72.8 \%)$ in the seagrass quadrats, followed by Copepoda (13.7\%) and Polychaeta (6.1\%). However, Copepoda accounted for $45.2 \%$ and dominated the unvegetated site, followed by Nematoda (35.4\%), nauplius (10.3\%), and Polychaeta (5.2\%). The remaining groups represented less than $6 \%$ of total meiofauna.

Regarding nematodes, densities within each sample ranged from 51 to 2,682 individuals $10 \mathrm{~cm}^{-2}$. A total of 63 nematode genera belonging to 20 families were identified from 1,680 individuals (Table 2). Ten genera (6.3\% of total) were restricted to unvegetated sediments, and 30 genera $(47.6 \%)$ solely occurred in seagrass beds. Daptonema was the most dominant genus and accounted for similar percentages in both habitats, whereas most genera (44 genera) made poor contributions $(<1 \%$ of total abundance). Four genera, i.e., Daptonema, Perspiria, Robbea, and Paralinhomoeus, contributed 50.2\% to the total nematode abundance at seagrass sites, whereas three genera, i.e., Daptonema, Longicyatholaimus, and Spirinia, made a larger contribution to the abundance $(60.1 \%)$ at the adjacent unvegetated site.

\section{Consistency of core replicates}

The univariate analyses cannot detect any significant differences in meiofaunal abundance, nematode abundance, and nematode diversity between seagrass and unvegetated habitats. According to the multivariate analysis, most subsamples were clustered at a high similarity level $(>0.80)$ for higher meiofaunal taxa, whereas replicates of various habitats were undetermined and combined randomly (Figure 2a). For nematode genera, all replicates from the seagrass quadrats were clustered to a single group at a similarity level of 0.51 , whereas one unvegetated replicate was highly dissimilar from the others (Figure $2 \mathrm{~b}$ ).

The results of CA were similar to what cluster analysis displayed. For higher meiofaunal taxa, the eigenvalues of the first three axes were $0.207,0.145$, and 0.078 and accounted for $27.7 \%, 19.5 \%$, and $10.4 \%$ of the variation, respectively (Figure 3a). Except for one seagrass replicate (SEC3 in Figure 3a, which possessed rare taxa, i.e., the only rotifer in this study and a sipunculan) in the second quadrant, the other replicates were positioned near the origin and distributed along the first axis. A seagrass replicate (SEB5 in Figure 3a, which possessed the fewest nematodes showing a low nematode/copepod ratio as in the unvegetated samples) and the unvegetated samples were aggregated together. For nematode genera, the eigenvalues of the first three axes were 0.582, 0.287, and 0.254 and accounted for $21.5 \%, 10.6 \%$, and $9.4 \%$ of the variation, respectively (Figure $3 \mathrm{~b}$ ). In addition to one unvegetated replicate (SC4 in Figure 3b, which revealed an extremely distinct generic composition from the other replicates: 71 individuals of Longicyatholaimus, 10 of Mesacanthion, and 2 rare taxa, Oxystomina and Thalassironus, only appearing in this sample) in the fourth quadrant, the other replicates were distributed along the second axis. All seagrass replicates were located near the origin and well separated from the replicates of unvegetated sediments. The non-metric multidimensional scaling (MDS) ordination for meiofauna and nematodes (data not shown) both represented a considerable degree of similarity to the results of CA but with a high stress value (0.16).

Cluster analysis and CA revealed that the nematodes showed dissimilar community structures between seagrass beds and unvegetated sediments. Therefore, the randomization test was constructed afterward only according to the seagrass samples.

\section{Randomization test}

All of the 15 cores from seagrass quadrats were combined in this analysis. For meiofauna, the mean abundance of the seagrass samples (i.e., 368 individuals) was used to simulate a sample size for the randomization test. The cumulative diversity curve (Figure $4 \mathrm{a}$ ) flattened from the first sample size $(n=368)$ to the total abundance $(n=5,521$; $\left.H^{\prime}=1.0\right)$, and the Kruskal-Wallis test showed no significant 
Table 2 Percentages of nematode genera from seagrass beds and adjacent unvegetated sediments at Shihlang, Ludao

\begin{tabular}{|c|c|c|c|c|}
\hline Nematode genus & Family & Trophic type & Seagrass & Unvegetated \\
\hline Acanthonchus & Cyatholaimidae & $2 \mathrm{~A}$ & 0.2 & 0.0 \\
\hline Alaimella & Leptolaimidae & $1 \mathrm{~A}$ & 0.1 & 0.0 \\
\hline Anticoma & Anticomidae & $1 \mathrm{~A}$ & 1.3 & 0.3 \\
\hline Bathyeurystomina & Enchelidiidae & $2 \mathrm{~B}$ & 0.2 & 0.0 \\
\hline Calyptronema & Enchelidiidae & $2 \mathrm{~B}$ & 0.2 & 0.0 \\
\hline Camacolaimus & Leptolaimidae & $2 \mathrm{~A}$ & 0.5 & 0.0 \\
\hline Chromadorina & Chromadoridae & $2 \mathrm{~A}$ & 1.1 & 0.0 \\
\hline Chromadorita & Chromadoridae & $2 \mathrm{~A}$ & 6.1 & 3.4 \\
\hline Daptonema & Xyalidae & $1 \mathrm{~B}$ & 21.2 & 23.3 \\
\hline Demonema & Selachnematidae & $2 \mathrm{~B}$ & 0.3 & 0.0 \\
\hline Desmodora & Desmodoridae & $2 \mathrm{~A}$ & 0.1 & 0.6 \\
\hline Desmodorella & Desmodoridae & $2 \mathrm{~A}$ & 0.0 & 0.3 \\
\hline Desmolaimus & Linhomoeidae & $1 \mathrm{~B}$ & 1.2 & 0.3 \\
\hline Dichromadora & Chromadoridae & $2 \mathrm{~A}$ & 0.0 & 0.6 \\
\hline Diodontolaimus & Leptolaimidae & $2 \mathrm{~A}$ & 1.1 & 0.0 \\
\hline Elzalia & Xyalidae & $1 \mathrm{~B}$ & 0.8 & 0.3 \\
\hline Epsilonema & Epsilonematidae & $1 \mathrm{~A}$ & 1.7 & 2.0 \\
\hline Eubostrichus & Desmodoridae & $1 \mathrm{~A}$ & 0.0 & 1.1 \\
\hline Eurystomina & Enchelidiidae & $2 \mathrm{~B}$ & 0.2 & 0.3 \\
\hline Filoncholaimus & Oncholaimidae & $2 \mathrm{~B}$ & 0.1 & 0.0 \\
\hline Gammanema & Selachnematidae & $2 \mathrm{~B}$ & 0.2 & 0.3 \\
\hline Graphonema & Chromadoridae & $2 \mathrm{~A}$ & 0.0 & 6.0 \\
\hline Halalaimus & Oxystominidae & $1 \mathrm{~A}$ & 0.5 & 0.0 \\
\hline Halaphanolaimus & Leptolaimidae & $1 \mathrm{~A}$ & 0.2 & 0.0 \\
\hline Halichoanolaimus & Selachnematidae & $2 \mathrm{~B}$ & 0.4 & 0.9 \\
\hline Leptolaimus & Leptolaimidae & $1 \mathrm{~A}$ & 0.5 & 0.0 \\
\hline Longicyatholaimus & Cyatholaimidae & $2 \mathrm{~A}$ & 0.0 & 22.1 \\
\hline Megadesmolaimus & Linhomoeidae & $1 \mathrm{~B}$ & 0.5 & 0.0 \\
\hline Mesacanthion & Thoracostomopsidae & $2 \mathrm{~B}$ & 0.1 & 3.2 \\
\hline Metachromadora & Desmodoridae & $2 \mathrm{~A}$ & 4.9 & 0.9 \\
\hline Metalinhomoeus & Linhomoeidae & $1 \mathrm{~B}$ & 3.0 & 0.0 \\
\hline Meyersia & Oncholaimidae & $2 B$ & 0.5 & 0.3 \\
\hline Microlaimus & Microlaimidae & $2 \mathrm{~A}$ & 0.2 & 0.0 \\
\hline Molgolaimus & Desmodoridae & $1 \mathrm{~A}$ & 0.9 & 0.0 \\
\hline Neochromadora & Chromadoridae & $2 \mathrm{~A}$ & 2.5 & 0.0 \\
\hline Odontanticoma & Anticomidae & $2 \mathrm{~A}$ & 0.1 & 0.0 \\
\hline Oncholaimus & Oncholaimidae & $2 \mathrm{~B}$ & 2.0 & 1.4 \\
\hline Oxystomina & Oxystominidae & $1 \mathrm{~A}$ & 0.0 & 0.6 \\
\hline Paracyatholaimus & Cyatholaimidae & $2 \mathrm{~A}$ & 0.9 & 0.0 \\
\hline Paralinhomoeus & Linhomoeidae & 1B & 7.4 & 3.4 \\
\hline Perspiria & Desmodoridae & $2 \mathrm{~A}$ & 13.4 & 0.6 \\
\hline Phanoderma & Phanodermatidae & $2 \mathrm{~A}$ & 0.2 & 0.0 \\
\hline Phanodermella & Phanodermatidae & $1 \mathrm{~A}$ & 0.2 & 0.0 \\
\hline Pomponema & Cyatholaimidae & $2 \mathrm{~A}$ & 0.6 & 2.0 \\
\hline
\end{tabular}


Table 2 Percentages of nematode genera from seagrass beds and adjacent unvegetated sediments at Shihlang, Ludao (Continued)

\begin{tabular}{|c|c|c|c|c|}
\hline Prochromadorella & Chromadoridae & $2 \mathrm{~A}$ & 0.4 & 0.6 \\
\hline Promonhystera & Xyalidae & $1 \mathrm{~B}$ & 0.1 & 0.0 \\
\hline Pseudocella & Leptsomatidae & $2 \mathrm{~A}$ & 0.3 & 0.0 \\
\hline Pseudochromadora & Desmodoridae & $2 \mathrm{~A}$ & 5.9 & 1.7 \\
\hline Pseudonchus & Desmodoridae & $2 B$ & 0.0 & 1.7 \\
\hline Rhinema & Monoposthiidae & $2 \mathrm{~A}$ & 0.9 & 0.0 \\
\hline Robbea & Desmodoridae & $1 \mathrm{~A}$ & 8.1 & 0.6 \\
\hline Spilophorella & Chromadoridae & $2 \mathrm{~A}$ & 2.6 & 4.3 \\
\hline Spirinia & Desmodoridae & $2 \mathrm{~A}$ & 0.5 & 14.7 \\
\hline Steineria & Xyalidae & $1 \mathrm{~B}$ & 0.9 & 0.0 \\
\hline Symplocostoma & Enchelidiidae & $2 B$ & 0.1 & 0.0 \\
\hline Symplocostomella & Enchelidiidae & $2 B$ & 0.1 & 0.0 \\
\hline Synonchus & Leptsomatidae & $2 \mathrm{~A}$ & 0.1 & 0.0 \\
\hline Thalassironus & Ironidae & $2 B$ & 0.0 & 0.9 \\
\hline Thalassomonhystera & Monhysteridae & $1 \mathrm{~A}$ & 0.1 & 0.0 \\
\hline Theristus & Xyalidae & $1 \mathrm{~B}$ & 3.2 & 0.0 \\
\hline Trichotheristus & Xyalidae & $1 \mathrm{~B}$ & 0.0 & 0.3 \\
\hline Vasostoma & Comesomatidae & $2 \mathrm{~A}$ & 0.0 & 0.3 \\
\hline Viscosia & Oncholaimidae & $2 B$ & 1.7 & 0.9 \\
\hline
\end{tabular}

The percentages of the ten most dominant nematode genera for both habitats are shown in italics. Trophic type: 1A, selective deposit feeder; $1 \mathrm{~B}$, non-selective deposit feeder; $2 \mathrm{~A}$, epistrate feeder; $2 \mathrm{~B}$, predator or omnivore.

difference among the cumulative sample sizes. For nematodes, 100 individuals, the most commonly selected number for taxonomic identification, were used to simulate a given sample. After the two replicates $(n=200)$ were pooled, the cumulative diversity curve (Figure $4 \mathrm{~b}$ ) flattened to the total number of individuals $(n=1,332$; $H^{\prime}=2.9$ ). The Kruskal-Wallis test showed a significant difference among various sample sizes $(p<0.001)$. Only
100 and 200 individuals revealed significant differences from the other cumulative sample sizes. The cumulative sample size of 200 nematodes merely shows a significant difference with 1,300 individuals but is indistinguishable from the ultimate sample size $(n=1,332)$ by Dunn's test (Figure $4 \mathrm{~b}$ ). For reliably estimating the local diversity index of nematode genera, a cumulative sample size of at least 300 individuals is recommended.

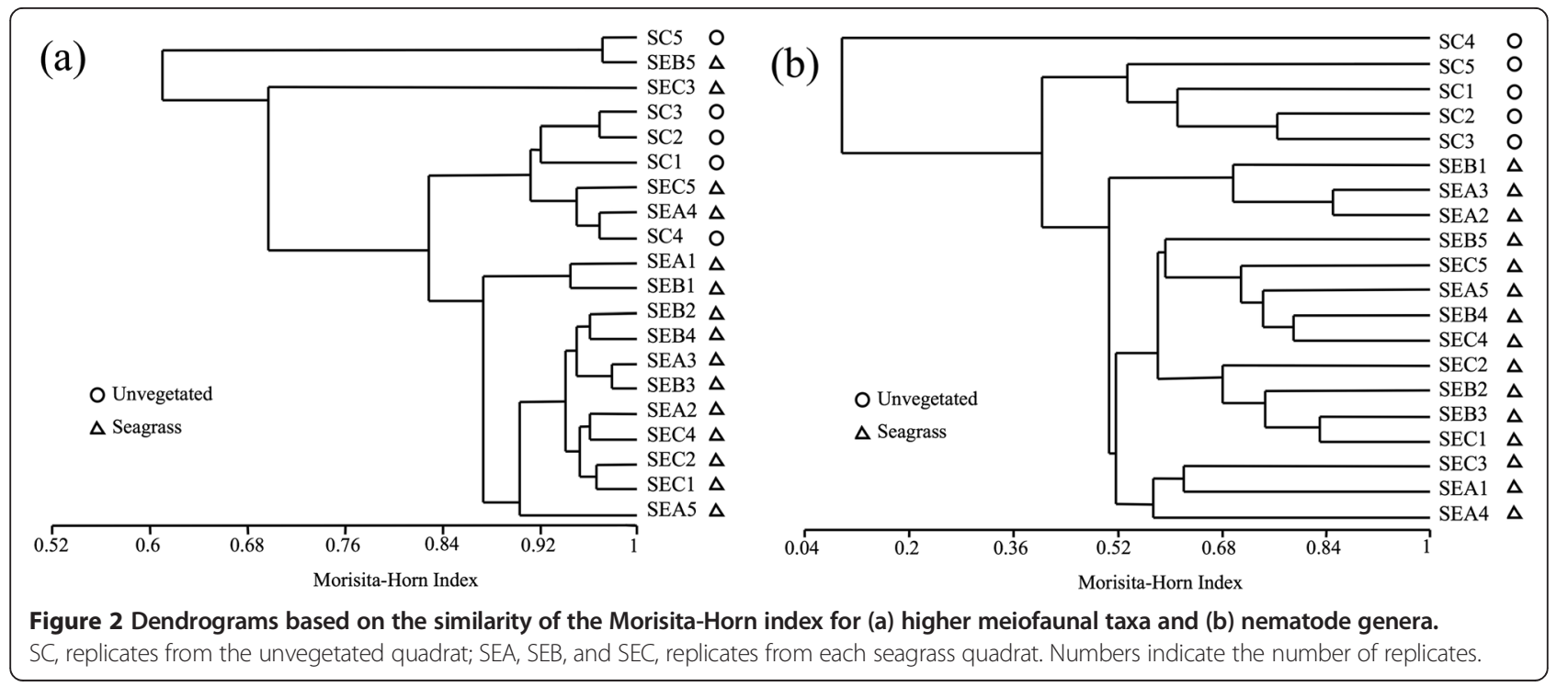




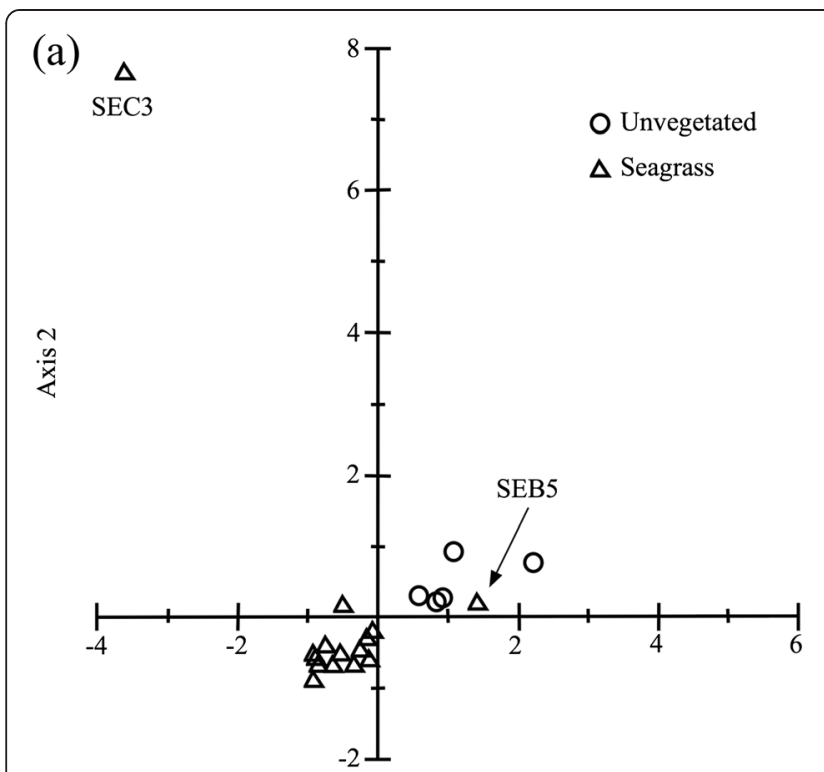

Axis 1

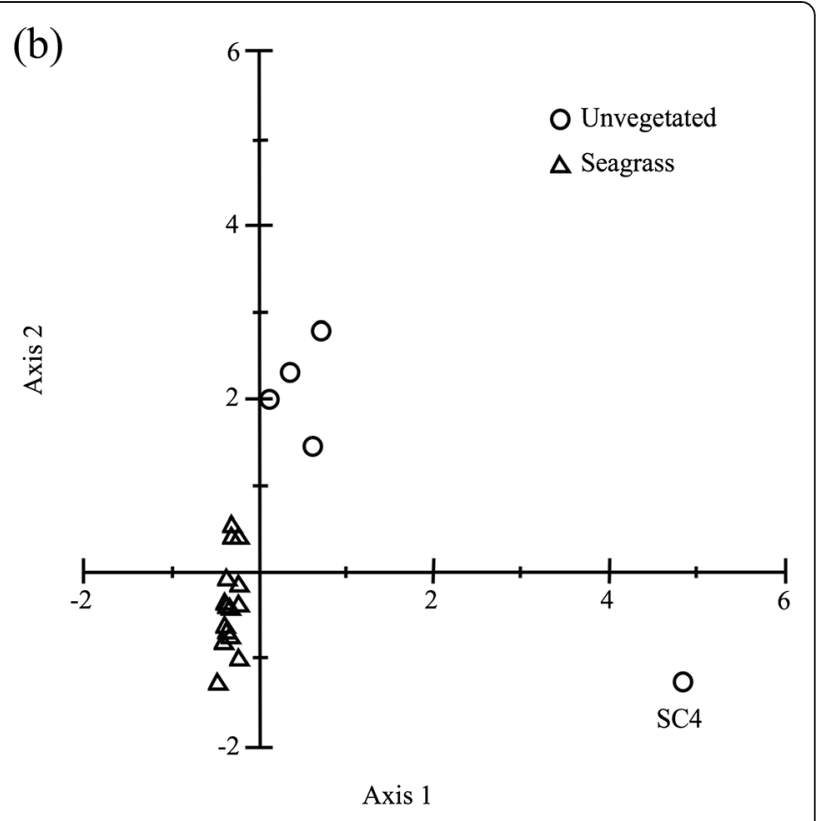

Axis 1

Figure 3 Scatterplots by correspondence analysis of (a) higher meiofaunal taxa and (b) nematode genera. The abundance data have been square root transformed.

\section{Discussion}

According to the multivariate analyses, the nematode abundance and diversity recorded in the seagrass bed being higher than those in the adjacent unvegetated sediments are consistent with previous studies (Castel et al. 1989; Danovaro et al. 2002; Hourston et al. 2005; Monthum and Aryuthaka 2006; Leduc and Probert 2011). However, an unexpected pattern was observed in this study where copepods display a reverse trend to nematodes, i.e., the abundance of copepods inside the seagrass bed is lower than that in the unvegetated area. Most surveys have mentioned that copepod densities are higher in seagrass beds (e.g., Hicks 1986; Ansari and Parulekar 1994; Ndaro and Ólafsson 1999; De Troch et al. 2001), but a contrary result has also been reported (Leduc and Probert 2011). Shallow seagrass beds may not substantially influence the abundance of copepods as the deeper ones do (De Troch et al. 2001). The abundance of copepods is positively related to the coarser sediments (Coull 1985), whereas sediments underneath seagrass are commonly finer than those of unvegetated areas. In addition, the dense canopies of seagrasses prevent the growth of microphytobenthos, which are the main diet of copepods (Leduc et al. 2009; Leduc and Probert 2011). The epibenthic and interstitial
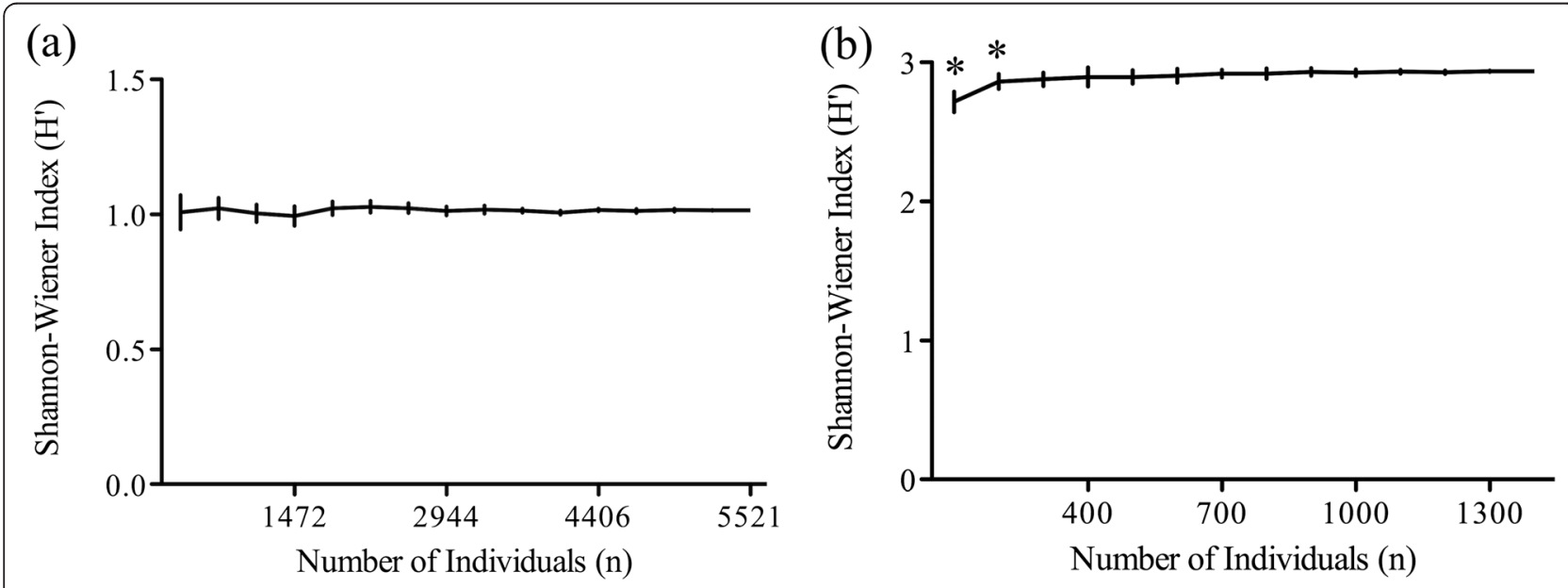

Figure 4 Results of the randomization test for (a) higher meiofaunal taxa and (b) nematode genera. Standard deviations are shown as vertical bars. The sample sizes with an asterisk reveal the significant differences of the Shannon-Wiener index from the other sample sizes. 
copepod taxa have distinct environmental demands and stress endurance (Hicks 1986; Giere 2009), so classifying subgroups of copepods may clarify their preference for the microhabitats in seagrass beds.

The seagrass samples bear a rough resemblance in meiofauna as revealed by multivariate analyses but with exceptions. The differences in meiofaunal communities between seagrass beds and adjacent unvegetated sediments may be hardly detectable at a meter scale, and most higher meiofaunal taxa, e.g., copepods and nauplii, have substantially higher dispersal rates than nematodes, which affect their temporary local distribution (Commito and Tita 2002). The active seagrass-associated taxa could forage for foods in peripheral unvegetated sediments but keep close to seagrass beds (Orth et al. 1984). The wave disturbance and salinity changes in the coastal region tend to mitigate small-scale patchiness and local diversity of nematodes (Lambshead and Boucher 2003). However, the compositions of nematode genera have various arrangements in this study, even at a scale within several meters.

Regarding the trophic types of nematodes, epistrate feeders (2A; trophic type by Wieser 1953) are generally dominant in sandy sediments and non-selective deposit feeders (1B) are highly abundant in muddy regions, whereas a recent study has pointed out that the trophic structure is coupling with the potential food sources rather than the other environmental factors (Danovaro and Gambi 2002). Daptonema, which possesses the highest percentage $(>20 \%)$ in both habitats, dominates wide seagrass habitats, especially in sandy sediments (Ndaro and Ólafsson 1999; Hourston et al. 2005; Fonseca et al. 2011). Although Daptonema has been treated as a non-selective deposit feeder, many trophic studies have found that they also feed on diatoms at the surface of sand grains and can be regarded as epistrate feeders (Heip et al. 1985; Moens and Vincx 1997). Comparing with the uniform distribution of Daptonema, most epistrate feeders (most members of Chromadoridae and Desmodoridae), which have the highest relative dispersal rate of nematodes (Commito and Tita 2002), show a substantial patchy colonization in this study. Many studies have also stated the dominance of epistrate feeders in seagrass sediments (e.g., Hopper and Meyers 1967; Ndaro and Ólafsson 1999; Danovaro and Gambi 2002; Fonseca et al. 2011). The seagrass samples consisted of $8.1 \%$ of Robbea, a selective deposit feeder (1A), which is coated with particular ectosymbiotic bacteria and occurred extremely rare $(0.6 \%)$ in unvegetated sediments. A similar deep-dwelling genus, Catanema, also dominates Australian seagrass beds (Fisher 2003; Fisher and Sheaves 2003).

Freshwater input in the sampling site (20 PSU during sampling occurrence) allows salinity-tolerant nematodes, including Chromadorita, Daptonema, Metachromadora,
Metalinhomoeus, Paralinhomoeus, Pomponema, Spilophorella, Spirinia, and Theristus (Heip et al. 1985), to occur as the dominant genera. The salinity stress drives the abundance of few euryhaline species while rich nutrient supply by seagrass creates a luxuriant microbial food resource, which attracts the rare deposit-feeding nematodes from peripheral sediments (Fisher and Sheaves 2003). Definite differences are present in nematode assemblages between both habitats, and shifts in nematode generic composition have occurred on a meter scale. For Chromadoridae, Chromadorina and Neochromadora are restricted to seagrass beds, whereas Dichromadora and Graphonema are restricted to unvegetated sediments. For Desmodoridae, Robbea, Metachromadora, Perspiria, and Pseudochromadora are dominant in seagrass beds, whereas Eubostrichus, Pseudonchus, and Spirinia are restricted to or dominant in unvegetated sediments. Various genera of the same family may have distinct preferences for vegetated and unvegetated habitats, or the distribution pattern could be the competitive result in which similar species compete for the plentiful food sources in seagrass sediments. In addition to the chromadorids, desmodorids, and xyalids common to both habitats, linhomoeids (e.g., Paralinhomoeus and Metalinhomoeus) are obviously occurring in seagrass beds, whereas cyatholaimids (e.g., Longicyatholaimus) dominate in unvegetated sediments. Linhomoeids are also restricted to the seagrass beds in Australia, and it has been suggested that they are tolerant to high organic matter content and hypoxia in the sediments underneath seagrasses (Fonseca et al. 2011). Paralongicyatholaimus, which resembles Longicyatholaimus, is the dominant genus in seagrass beds and adjacent unvegetated area in Thailand (Monthum and Aryuthaka 2006).

Regarding local seagrass beds, only a single core or a cumulative sample size of 368 individuals is sufficient for estimating the diversity of meiofauna, but at least three cores or a cumulative sample size of 300 individuals is needed for nematode diversity. The taxonomic categories (family, genus, or species) obviously influence the requirements of appropriate sample sizes. The Shannon-Wiener index $\left(H^{\prime}\right)$, used as a criterion for the randomization test, is less sample size dependent than Hill's $N_{1}$ index (Hill 1973; Soetaert and Heip 1990), but $H^{\prime}$ has still been applied extensively to compare community diversity and provides an appropriate estimate for a community structure. The diversity of nematodes $\left(H^{\prime}=2.9\right)$, albeit only for genera, is lower than the species diversity in Thailand (3.4 to 3.7; Monthum and Aryuthaka 2006) but resembles the Australian values (2.66 to 3.5; Fisher and Sheaves 2003). The nematode assemblages dominate by a small number of taxa but still show moderate diversity in tropical seagrass beds (Fisher and Sheaves 2003).

At least 300 individuals are recommended for steady estimation of the local diversity of nematode genera. 
However, 6 out of 15 of the seagrass samples and 3 out of 5 of the unvegetated samples possess less than 100 individual nematodes in this study. The use of cores with fairly wide diameters (e.g., $3.6 \mathrm{~cm}$ ) is suggested for achieving reliable quantitative data. A similar result showed that two $10-\mathrm{cm}^{2}$ subsampling cores are required to monitor nematode genus diversity in subtidal stations of the North Sea (Li et al. 1997). Water flows or bioturbated activities improve oxygen penetration in sandy habitats and then induce vertical migration of nematodes to a deeper (beneath $5 \mathrm{~cm}$ ) sediment layer (Steyaert et al. 2003; Giere 2009). The seagrass bed in Shihlang possesses a large amount of coarse sands, where nematodes tend to distribute more deeply (McLachlan et al. 1977; Heip et al. 1985), and thus, the vertical profile of the nematode community can be clarified by sampling deeper than 5 - or $10-\mathrm{cm}$ depths (Steyaert et al. 2003; Leduc and Probert 2011).

\section{Conclusions}

The community structure of marine nematode genera distinguishes the seagrass habitats from adjacent unvegetated sediments at a scale within several meters, whereas higher meiofaunal taxa are undetermined according to multivariate analysis. The copepod abundance is unexpectedly higher in peripheral unvegetated habitats than in seagrass beds in the present study. Classifying copepods into epibenthic or interstitial subgroups may elucidate their preference for microhabitats. Regarding nematodes, Daptonema, a non-selective deposit feeder, dominates both habitats. Longicyatholaimus is abundant and restricted to unvegetated sediments, whereas some genera, e.g., Perspiria and Robbea, are restricted to dominating in sediments under seagrass. According to randomization analysis, only a single core can reliably estimate meiofaunal diversity, whereas three cores are sufficient to estimate the local diversity of nematodes. Albeit the unvegetated areas may not contain as diverse infauna as vegetated sediments, they could be a matrix habitat and provide corridors between fragmented seagrass patches (Boström et al. 2006). In addition, both habitats compose specific infauna, and the unvegetated site should also be considered in the conservation strategy for seagrass.

\section{Competing interests}

The authors declare that they have no competing interests.

\section{Authors' contributions}

$J X L$ designed and carried out the experiment. JXL and HMY analyzed the data. JXL, HMY, and HKM finalized the manuscript. All authors read and approved the final manuscript.

\section{Acknowledgements}

We thank Shih-Wei Su and Yen-Wei Chang for their help in the fieldwork. We are grateful to two anonymous reviewers for their constructive suggestion.

\section{Author details}

'Department of Oceanography, National Sun Yat-sen University, Lienhai Road 70, Kaohsiung 80424, Taiwan. ${ }^{2}$ Coastal and Offshore Resources Research Center, Fisheries Research Institute, Yugang North 3rd Road 6, Kaohsiung 80672, Taiwan.

Received: 26 August 2014 Accepted: 30 December 2014

Published online: 16 January 2015

\section{References}

Ansari ZA, Parulekar AH (1994) Meiobenthos in the sediment of seagrass meadows of Lakshadweep atolls, Arabian Sea. Vie Milieu 44:185-190

Atilla N, Fleeger JW, Finelli CM (2005) Effects of habitat complexity and hydrodynamics on the abundance and diversity of small invertebrates colonizing artificial substrates. J Mar Res 63:1151-1172

Bongers T, Ferris H (1999) Nematode community structures as a bioindicator in environmental monitoring. Trends Ecol Evol 14:224-228

Boström C, Jackson EL, Simenstad CA (2006) Seagrass landscapes and their effects on associated fauna: a review. Estuar Coast Shelf Sci 68:383-403

Castel J, Labourg PJ, Escaravage V, Auby I, Garcia ME (1989) Influence of seagrass beds and oyster parks on the abundance and biomass patterns of meio- and macrobenthos in tidal flats. Estuar Coast Shelf Sci 28:71-85

Commito JA, Tita G (2002) Differential dispersal rates in an intertidal meiofauna assemblage. J Exp Mar Biol Ecol 268:237-256

Coull BC (1985) Long-term variability of estuarine meiobenthos: an 11 year study. Mar Ecol Prog Ser 24:205-218

Danovaro R, Gambi C (2002) Biodiversity and trophic structure of nematode assemblages in seagrass system: evidence for a coupling with changes in food availability. Mar Biol 141:667-677

Danovaro R, Gambi C, Mirto S (2002) Meiofaunal production and energy transfer efficiency in a seagrass Posidonia oceanica bed in the western Mediterranean Mar Ecol Prog Ser 234:95-104

De Troch M, Gurdebeke S, Fiers F, Vincx M (2001) Zonation and structuring factors of meiofauna communities in a tropical seagrass bed (Gazi Bay, Kenya). J Sea Res 45:45-61

Duarte CM, Chiscano CL (1999) Seagrass biomass and production: a reassessment. Aquat Bot 65:159-174

Fisher R (2003) Spatial and temporal variations in nematode assemblages in tropical seagrass sediments. Hydrobiologia 493:43-63

Fisher R, Sheaves MJ (2003) Community structure and spatial variability of marine nematodes in tropical Australian pioneer seagrass meadows. Hydrobiologia 495:143-158

Fonseca G, Hutchings P, Gallucci F (2011) Meiobenthic communities of seagrass beds (Zostera capricorni) and unvegetated sediments along the coast of New South Wales, Australia. Estuar Coast Shelf Sci 91:69-77

Giere $O$ (2009) Meiobenthology: the microscopic motile fauna of aquatic sediments, 2nd edn. Springer-Verlag, Berlin

Hall MO, Bell SS (1993) Meiofauna on the seagrass Thalassia testudium-population characteristics of harpacticoid copepods and associations with algal epiphytes. Mar Biol 116:137-146

Heip C, Vincx M, Vranken G (1985) The ecology of marine nematodes. Oceanogr Mar Biol Ann Rev 23:399-489

Hicks GRF (1986) Distribution and behaviour of meiofaunal copepods inside and outside seagrass beds. Mar Ecol Prog Ser 31:159-170

Hill MO (1973) Diversity and evenness: a unifying notation and its consequences. Ecology 54:427-432

Hodda M (1990) Variation in estuarine littoral nematode populations over three spatial scales. Estuar Coast Shelf Sci 30:325-340

Hopper BE, Meyers SP (1967) Population studies on benthic nematodes within a subtropical seagrass community. Mar Biol 1:85-96

Horn HS (1966) Measurement of "overlap" in comparative ecological studies. Am Nat 100:419-424

Hourston M, Warwick RM, Valesini FJ, Potter IC (2005) To what extent are the characteristics of nematode assemblages in nearshore sediments on the west Australian coast related to habitat type, season and zone? Estuar Coast Shelf Sci 64:601-612

Hurlbert SH (1971) The non-concept of species diversity: a critique and alternative parameters. Ecology 52:577-586

Josefson AB, Widbom B (1988) Differential response of benthic macrofauna and meiofauna to hypoxia in the Gullmar Fjord basin. Mar Biol 100:31-40 
Lambshead PJD, Boucher G (2003) Marine nematode deep-sea biodiversity hyperdiverse or hype? J Biogeogr 30:475-485

Leduc D, Probert PK (2011) Small-scale effect of intertidal seagrass (Zostera muelleri) on meiofaunal abundance, biomass, and nematode community structure. J Mar Biol Ass UK 91:579-591

Leduc D, Probert PK, Duncan A (2009) A multi-method approach for identifying meiofaunal trophic connections. Mar Ecol Prog Ser 383:95-111

Leduc D, Probert PK, Nodder SD (2010) Influence of mesh size and core penetration on estimates of deep-sea nematode abundance, biomass, and diversity. Deep-Sea Res I 57:1354-1362

Legendre P, Legendre L (1998) Numerical ecology, 2nd English edition. Elsevier Science B. V, Amsterdam

Li J, Vincx M, Herman PMJ, Heip C (1997) Monitoring meiobenthos using cm-, m- and km-scales in the Southern Bight of the North Sea. Mar Env Res 43:265-278

McLachlan A, Erasmus T, Furstenberg JP (1977) Migrations of sandy beach meiofauna. Zool Afr 12:257-277

Mills VS, Berkenbusch K (2009) Seagrass (Zostera muelleri) patch size and spatial location influence infaunal macroinvertebrate assemblages. Estuar Coast Shelf Sci 81:123-129

Moens T, Vincx M (1997) Observations on the feeding ecology of estuarine nematodes. J Mar Biol Ass UK 77:211-227

Monthum Y, Aryuthaka C (2006) Spatial distribution of meiobenthic community in Tha Len seagrass bed, Krabi Province, Thailand. Coast Mar Sci 30:146-153

Ndaro S, Ólafsson E (1999) Soft-bottom fauna with emphasis on nematode assemblage structure in a tropical intertidal lagoon in Zanzibar, eastern Africa: I. Spatial variability. Hydrobiologia 405:133-148

Orth RJ, Heck KL Jr, van Montfrans J (1984) Faunal communities in seagrass beds: a review of the influence of plant structure and prey characteristics on predator-prey relationships. Estuaries 7:339-350

Osenga GA, Coull BC (1983) Spartina alterniflora Loisel root structure and meiofaunal abundance. J Exp Mar Biol Ecol 67:221-225

Platt HM, Warwick RM (1988) Free-living marine nematodes. Part II. British chromadorids, Brill/Backhuys, Leiden

Sanders HL (1968) Marine benthic diversity: a comparative study. Am Nat 102:243-282

Shimanaga M, Kitazato H, Shirayama Y (2004) Temporal patterns in diversity and species composition of deep-sea benthic copepods in bathyal Sagami Bay, central Japan. Mar Biol 144:1097-1110

Soetaert K, Heip C (1990) Sample-size dependence of diversity indices and the determination of sufficient sample size in a high-diversity deep-sea environment. Mar Ecol Prog Ser 59:305-307

Steyaert M, Vanaverbeke J, Vanreusel A, Barranguet C, Lucas C, Vincx M (2003) The importance of fine-scale, vertical profiles in characterising nematode community structure. Estuar Coast Shelf Sci 58:353-366

Warwick RM, Platt HM, Somerfield PJ (1998) Free-living marine nematodes. Part III. Monhysterids, Field Studies Council, Shrewsbury

Wieser W (1953) Die Beziehung zwischen Mundhöhlengestalt, Ernährungsweise und Vorkommen bei freilebenden marinen Nematoden. Arkiv Zoologi 4:439-484

Yeh HM, Ohta S (2002) Influence of velocity and types of beam trawl towing on deep-sea demersal fish and decapod crustacean samples. J Oceanogr 58:505-517

\section{Submit your manuscript to a SpringerOpen ${ }^{\circ}$ journal and benefit from:}

- Convenient online submission

- Rigorous peer review

- Immediate publication on acceptance

- Open access: articles freely available online

- High visibility within the field

- Retaining the copyright to your article

Submit your next manuscript at $>$ springeropen.com 